\title{
Historiographical Overview of the Researches on the Problem of the Population's Attitude to New Sources of Energy
}

\author{
Ksenia V. Reznikova* and Yulia S. Zamaraeva \\ Siberian Federal University \\ 79 Svobodny, Krasnoyarsk, 660041, Russia
}

Received 14.07.2017, received in revised form 12.08.2017, accepted 24.08.2017

\begin{abstract}
International science faced the topic of the attitude to new sources of energy in the 1990s, though domestic scientists still do not pay proper attention to this problem. In the field of studying the attitude to new sources of energy abroad, the 1990s also became a turning decade, which was followed by a transition in understanding what is a new source of energy: as such, nuclear power is gradually losing its popularity, giving way to the new ones, i.e. renewable energy sources. This trend in science since its inception and to the present time is widespread, mainly, in Europe and the United States - in those regions in the economies of which new sources of energy begin to play significant roles.
\end{abstract}

Keywords: global climate change, new sources of energy, renewable energy sources, attitude of the population, historiography of the study of new sources of energy.

The reported study was funded by the Russian Foundation for Basic Research, Government of the Krasnoyarsk Territory, Krasnoyarsk Region Science and Technology Support Fund within the framework of the research project No. 17-16-24601.

DOI: 10.17516/1997-1370-0145.

Research area: culturology.

The article analyzes publications of the 70-years long period - from 1950 to 2017 both in Russia and abroad, relating to the attitude towards new sources of energy. Energy, according to L. White, is a factor determining the development of culture (White, 2004). He meant only the energy that is involved in the human life through the use of more and more advanced technological devices. L. White believed that culture does not develop smoothly, but in a spasmodic manner, and each peak of development is associated with the discovery of the possibility of using a new source of energy. L. White singled out three main stages of human development: agrarian, fuel and nuclear. The end of the $20^{\text {th }}$ - beginning of the $21^{\text {st }}$ century have been marked by the search of humanity for new sources of energy that can replace fossil sources and nuclear energy, and probably will lead to a new breakthrough in culture. The article provides a historiographical overview of the research on the attitude to new sources of energy. Each

(C) Siberian Federal University. All rights reserved

* Corresponding author E-mail address: axu-ta@mail.ru 
time block (five in total) will include reviews of international and domestic research.

\section{Studies of the Attitude towards} New Sources of Energy in 1950s-1960s.

Judging by the works published in the 1950s-1960s there were no studies abroad devoted to the relation to new sources of energy. A new source of energy at that time was nuclear, or atomic energy. And scientific research is devoted to legislation regulating the use of nuclear energy (Kuper, 1954; Ruebhausen, Mehren, 1953); features of the economy based on nuclear energy (Schurr, 1965; Ruebhausen, Mehren 1953; Cockcroft, 1950; Dahl, Brown, 1952); nuclear industry in various countries, including the USSR (Kramish, 1959; Goldschmidt, 1962); and, of course, the use of atomic energy for peaceful, not military purposes (Bhabha, 1955).

In the 1950s and 1960s, scientists were interested in the sources of stellar energy (Unsold, 1958, Vorontsov-Velyaminov, 1959), the evolution of galaxies (Ambartsumian, 1958), the origin of chemical elements (Frank-Kamenetsky, 1959) and cosmic rays (Ginzburg, 1960), atomic energy (Post, 1957), mineralogy and geochemistry (Fersman, 1959).

\section{Studies of the Attitude towards}

\section{New Sources of Energy in 1970s-1980s}

In international studies, there is a scientific dilemma in the future use of nuclear power: some scientists call it a future source of energy, others warn of its threat to the world's population. In 1973, a conference on the energy policy and the new international system (Delhi, India) was held, and scientists came to the conclusion that the global energy policy depends on conventional nuclear power engineering (Fusion reactors as future energy sources, 1973). Later, other scientists write about the exclusion of the use of nuclear energy: B. Commoner also describes a plan for the transition to a new energy system that reduces the demand for nuclear energy, as well as renewable energy sources, the development of the National Energy Plan that increases the consumption of non-renewable energy (Commoner, 1979). Solar hydrogen is called a new energy carrier, excluding the use of nuclear energy (Bockris, 1975). Throughout the period the following areas had been studied: the radiativeconvective modeling of the climate problem (Manabe, 1977), the new quanta of galactic energy sources (Hermsen, 1977), the threats of acid rain as regional environmental problems (Likens, 1974), the new energy technologies (Hottel, 1971), extragalactic radio sources (Rees, 1971). Energy systems (11 systems, 6 of which threaten human health), the cycle of energy production are described (Inhaber, 1979).

Domestic researchers in the 1970s and 1980s paid attention not to studying the attitude to new sources of energy, but their use. Under the new source they mean nuclear energy only, which is directly called "the energy of the future". Along with the broadest possible coverage of atomic energy issues (Protsenko, 1985), narrower studies were also conducted touching upon the legal issues of using nuclear energy (Misharin, 1986; Burgasov et al., 1986), and also considering atomic energy as fuel for missiles, which opens up previously inaccessible space exploration opportunities (Avduyevskiy, 1986; Alemasov, 1980).

\section{Studies of the Attitude towards New Sources of Energy in 1990s}

Although in the 1990s in academic circles abroad, the appeal to nuclear energy research continues, the emphasis shifts towards the utilization of the military nuclear field (Lyman, 1996), and also towards the use of nuclear energy in space in the aspect of the attitude of environmentalists, activists, engineers and the 
general public (Maharik, Fischhoff, 1993). The work of M. Maharik and V. Fischhoff is aimed at identifying the factors that form the attitude to the risks of using nuclear energy in space, and ways of effective risk communication. R. Löfstedt conducts his research aimed at studying the attitude of the Swedes to various sources of energy that could replace nuclear power (Löfstedt, 1991); while R. Löfstedt is interested in both the economic and environmental aspects of the attitude to new sources of energy.

In the 1990s abroad, there are studies devoted to new sources of energy, such as renewable sources - wind, water flow, etc. P. Gipe examines the attitude of American respondents to four sources of energy - fossil, nuclear, solar and wind, the two latter being renewable (Gipe, 1990); the author comes to the conclusion that renewable sources are of priority in comparison with non-renewable ones. The fact of popular support for renewable energy sources, in particular, the wind, is confirmed by S. Krohn and S. Damborg (Krohn, 1999), noting that the level of support for the wind energy depends on the local experience of respondents in applying it. The research of J.M. Loiter and V. Norberg-Bohm is also devoted to the wind energy, but the authors approach the study of this renewable energy source in terms of its commercial payback and profitability and conclude that the widespread use of the wind energy is possible only with effective public policy involvement (Loiter, Norberg-Bohm, 1999). The development of the market for renewable energy sources cannot do without not only state support, but without sufficient qualified personnel, as indicated by M.Yu. Othman and K. Sopian (Othman, Sopian, 1999), offering a curriculum on renewable energy for universities.

Domestic studies develop the thought of the necessity to move from the use of the nuclear energy to the new sources supporting this necessity by the concept of V.I. Vernandsky's theory (from biosphere to anthroposphere).

Researchers are discussing the declaration "Agenda for the $21^{\text {st }}$ Century" signed by the heads of the states at the UN conference (Koptyug, 1992; Danilov-Danilyan, Losev, 1998). Thus, A.V. Avrorin, I.A. Ogorodnikov, G.V. Chernova, E.A. Chinnov suggest the strategy for transition to energy saving and environmental production, and the use of alternative, environmentally friendly energy sources (Avrorin et al., 1997). A.D. Yanshin writes that the man has already got accustomed to nuclear power, which led to a huge increase in the consumption of natural resources. Now it is necessary to form the person's ecological consciousness according to the concept of the anthroposphere of V.I. Vernadsky, it is now the age of realization that the humanity is a part of this anthroposphere and will seek to expand natural resources (Yanshin, 1999). S.K. Shardyko explores the nuclear complex of the USSR and atomic energy, which has influenced the development of modern nuclear technologies, as well as the technical and technological development of industrial civilization (Shardyko, 1998). A.V. Yablokov investigates the myths of nuclear energy of the late $20^{\text {th }}$ century, and writes about the purposeful formation of public opinion towards the adoption of nuclear programmes and nuclear energy as clean energy. Among those causing environmental hazards are called: nuclear reactors and power plants that produce "inert" gases, tritium, radioactive oxygen and gas, uranium-plutonium fuel. The scientist writes that nuclear programmes are not economically effective, there is no need to build new nuclear power plants, it is necessary to develop a programme for the disposal of nuclear waste and, most importantly, to adopt a variant of the energy programme with gradual transition to nonnuclear sources of electricity (Yablokov, 1995). 
4. Studies of the Attitude towards New Sources of Energy in 2000s

Foreign publications in 2000-2010 are addressed to the younger generation in order to understand their attitude to new sources of energy and the need to introduce new academic disciplines about new sources of energy.

In 2009, the results of a questionnaire of Turkish students aged 13-14 regarding their attitude to renewable energy sources were published. Half of the respondents expressed the view that it would be economically cheaper to generate energy from renewable energy sources, since they are safe for plants and animals; that the capacity of renewable energy sources is high and stable, that it will reduce global warming (Kilinc et al., 2009). S. Avadanei's article refers to the need to introduce in the educational process a course on nuclear physics, which is important for modern medicine and nuclear power. The knowledge of nuclear physics contributes to the formation of a correct perception in the society of the real risks of nuclear use. Beginning with primary school education, the younger generation will be able to adequately perceive information about nuclear safety and become specialists in this field (nuclear workers, radiation protection specialists). On the one hand, nuclear physics plays an important role in providing energy resources and reducing greenhouse gas emissions in the near future. On the other hand, nuclear physics will help uncover the mystery of the birth of the universe (Avadanei, 2009).

In the 2000s as before, domestic studies devoted to new sources of energy do not cover the issue of the attitude to these sources. But in addition to the research on nuclear power as a new source and the peculiarities of its use (Mesyatc, 2004; Canilo, 2016), they turn to non-traditional and renewable sources of energy - the energy of the wind, the Sun, small rivers (Magomedova, Balayantc, 2003; Mizhinskiy, Sigutina, 2008;
Tyukhov, 2009; Bagrova, 2009), and, what is important, it is discussed even in textbooks (Sokol'skiy, 2007, Lukutin, 2008), which indicates the existence of appropriate training courses in universities. E.M. Perminov writes about fuel and energy resources as the most important factor in the world politics and the development of the world economy. For Russia, it is necessary to develop decentralized renewable energy, which can solve the environmental problem (Perminov, 2007). Within the framework of domestic research, the increasing role of non-traditional and renewable energy sources, prospects for their use are being studied.

\section{Studies of the Attitude towards New Sources of Energy in 2010s}

In contrast to the research on the attitude towards the climate change, the research on the attitude towards new energy sources is not carried out everywhere, but in regions that have diversified their energy resources to some extent, replacing partially fossil energy sources with renewable ones. First of all, these are the countries of Europe and the USA. B.S. Steel, J.C. Pierce, R.L. Warner and N.P. Lovrich, researching the attitude of the population of the states of Oregon and Washington to government policies on the support of bioenergetics, wind energy, geothermal and solar energy in 20092010, found out that younger and more educated respondents tend to support the government in this matter (Steel et al., 2015).

R. Saha and J. Idsø study the attitude of Norway's municipalities to new, small scale hydropower as one of the renewable energy sources (Saha, Idsø, 2016). The authors note that Norway's policy is aimed at encouraging the use of renewable energy sources, which has resulted in the widespread development of small hydropower in the last decade and the reduction in the development of large 
hydropower. Nevertheless, the municipalities participate in the new hydropower in different ways, the reasons for the different attitudes were studied by R. Saha and J. Idsø using the system of motivational opportunities. The researchers came to the conclusion that it is not beliefs and attitudes being the main factor influencing the participation in the development of new hydropower, but motivation and participation opportunities, that is, in fact, local economic benefits are more important. The study of R. Klæboe and N.V. Sundfør is also devoted to investigation of the attitude to renewable energy, which is a "socio-acoustic survey" that they conducted because of the discontent of local residents with a windmill park (31 turbines) in the south of Norway (Klæboe, Sundfør, 2016). The respondents who are the participants in the local conflict appeal to the inconveniences associated with the noise from windmills, and with their unaesthetic appearance.

B. Mroczek and D. Kurpas investigated the attitude of the Poles (urban and rural residents, including those living at a distance of about 3 $\mathrm{km}$ from wind farms) to wind energy and other sources of renewable energy (Mroczek, Kurpas, 2014). According to the results of the study, the majority of respondents support the development of renewable energy, one in five is willing to pay for renewable sources more, appealing to lower $\mathrm{CO}_{2}$ emissions. The Poles believe that the development of wind energy contributes to maintaining the clean environment, creating new jobs, improving the country's energy security, technological progress, protecting human health, etc. A.N. Michel, M. Buchecker and N. Backhaus studied the perception of photovoltaic installations as a new source of energy (Michel et al., 2015). For them, it is important not only to study the attitude of local residents of the Swiss village to this installations, but also the attitude of tourists visiting this area in the Alps. The study showed, for example, that respondents do not perceive photovoltaic installations as a sharp invasion of the landscape, since they are not located on separate supports, but on existing anti-avalanche barriers.

S. Bigerna and R. Polinori investigated the mechanisms for the adoption of renewable energy in the case of the Italian region of Umbria and found that the central role in the adoption of renewable energy is played by the local community, and that respondents experienced in the use of wind energy are willing to pay more for the development of renewable energy sources (Bigerna, Polinori, 2015). F. Ribeiro, P. Ferreira, M. Araújo and A.S. Braga studied the attitude of the Portuguese towards renewable energy and found that all new sources of energy are widely supported by the population, especially solar energy as the most famous and economically viable source (Ribeiro et al., 2014). In general, the authors conclude that the Portuguese support the development of renewable energy, therefore, the introduction of it, probably, will not have any local confrontation in this country. S. Cebotari and J. Benedek, using the example of Romania's rural settlements, study not only the attitude towards renewable energy sources, but also take into account in their research the factor of who controls these sources - external managers or the rural communities themselves (Cebotari, Benedek, 2017). The second option, according to the results of the study, leads to the development of technologies in the field of renewable energy sources, to innovations related to politics.

Many scientists are investigating the attitude to new sources of energy not for the entire population of individual countries, but only for teenagers and young people. One of the simplest studies concerning the attitude of the population to new sources of energy was conducted by M.R. Culley, A.D. Carton, S.R. Weaver, E. Ogley-Oliver and J.C. Street, who interviewed 
277 students (Culley et al., 2011). The study showed that the potential support of a particular type of energy (including renewable sources, as well as fossil fuels), directly depends on the students' views on the relationship of this types with the provision of energy independence; and also revealed an inverse relationship between the support for the form of energy and ideas about its deleterious effect on the climate. K.M. Keramitsoglou does not investigate the relation of the representatives of the specific group to renewable energy sources, but focuses on the adolescents (from the Greek province) in order to adjust the educational process on the basis of the data obtained so as to form a proper attitude towards renewable energy sources, avoiding in the future the existing confusion in the energy issues, neutrality and indifference of adolescents to energy sources (Keramitsoglou, 2016).

A number of scientists are studying the attitude to new sources of energy in the light of the fact that the introduction of renewable energy in some regions has met a hostile reaction of local residents. In this regard, researchers seek to find channels of communication that can improve the attitude of the population to new sources of energy. N. Pidgeon and C.S. Demski attributed the importance of research on the attitude to new energy sources with the potential for rapid transition to non-carbon energy sources to prevent catastrophic climate change (Pidgeon, Demski, 2012). This is especially important in the view of the fact that some projects related to renewable energy sources have already faced negative public response. The authors propose to turn to the studies already conducted on the attitude to the use and placement of nuclear power facilities that have faced local opposition based on the absence of tangible local economic benefits, the threat of community identity, etc. The lack of established communication with representatives of the energy sector does not contribute to the public approval of new energy sources neither.

A.M. González, N. Sandoval, R. Acosta and F. Henao do not study the relation of the society to new sources of energy, but try to develop a conceptual model that would encourage the adoption of renewable energy sources by rural communities (González et al., 2016). The researchers base the importance of their work on the fact that, despite the environmental friendliness of new energy sources, their implementation quite regularly encounters social barriers on the part of local residents, which leads to a negative response to the new energy sector and its subsequent rejection. The authors have developed a model that involves the development of effective communication with rural communities to clarify the issues related to energy. F. Petrakopoulou studies the attitude of the population of one of the islands in the Mediterranean to renewable energy sources as an opportunity for energy autonomy (Petrakopoulou, 2017). In general, respondents are positive about renewable energy sources because of their environmental friendliness and the ability to provide energy independence. The respondents are inclined to consider the lack of political will on the part of the authorities as an obstacle to the wide spread of renewable energy. Questions related to clarifying information on new sources of energy are central in the work of S. Schonborn, A. Gellrich and M. David, who turned to studying the role of the local Protestant or Catholic Church in educating the population in the field of energy issues (Schonborn et al., 2014).

Domestic research in 2010-2017 does not include the study of public opinion on new sources of energy, most of the publications deal with the issue of the use of renewable energy sources both at the all-Russian and regional levels. Anthropogenic ecological reality is studied thoroughly, which should include modern 
technologies for consumption of renewable energy sources. A.G. Ershov, V.L. Shubnikov, L.A. Shultz represent technologies of heat treatment of waste as a replenishing source of energy for the needs of the society. At the same time, the authors are concerned that there is no desire on the part of state executive bodies to inform the population about the appearance of new technologies in this area (Ershov, 2014). L.N. Medvedeva, K.Yu. Kozenko, O.P. Komarova speak about the concept of the development of "green cities" as an innovative solution and an alternative source of energy (Medvedev, 2015). P.M. Canilo and A.L. Shubenko write about the need to develop thermal power, as nonrenewable natural energy (oil, natural gas) ends, and renewable energy resources require more efficient consumption (Canilo, 2017, Canilo, 2016). A.V. Ravino writes about the development of renewable energy sources, substantiating their economic component in achieving the principles of "improved growth" and "improved climate" (Ravino, 2016). O.Z. Engoyan analyzes the role of renewable energy in regional socio-economic systems that adapt to the climate change, and proposes to restore the principle of nonredundancy in the conduct of economic activity (Engoyan, 2011). There are articles devoted to the regional study of non-traditional and renewable energy sources (on the example of the Krasnodar Territory). At the same time, researcher write about the use of wind turbines and wind power plants on the seaside coast, solar collectors in heating and hot water supply systems, geothermal energy, biomass energy, energy of small rivers (for micro HPPs), solar power and heating stations (Amerkhanov et al., 2016, Amerkhanov et al., 2015).

There are studies related to the problems of the current climate state and the new principle of treating it in the world community. S.V. Avakyan emphasizes that modern global warming and growth of carbon dioxide concentration in the lower atmosphere are scientifically associated with solar-geomagnetic activity and low absorption of carbon dioxide by the remaining forests (Avakyan, Voronin, 2012). The energy factors of the processes are considered: natural (solar activity) and anthropogenic (gases of anthropogenic origin, large-scale forestry, urbanization, influence of radio transmitters on the environment). A.V. Prokofiev writes in 2011 about climate justice, which in the future should be realized through the principle of equality of "atmospheric rights". This is not about new sources of energy, but about ethical rules and requirements with respect to international cooperation in the field of preserving the climate balance of the planet and reducing the negative consequences of the climate change (Prokofiev, 2011).

\section{Conclusions}

The discussion of the attitude to new energy sources began in international science in the 1990s, in the domestic one such studies have not been determined.

In the 1950s and 1960s there were no studies abroad devoted to the relation to new sources of energy. At that time the issue of nuclear confrontation was acute and the atom was a new source of energy that was discussed by scientists in different contexts: in the legislative, economic, militaristic, etc.

In the $1970 \mathrm{~s}$ and $1980 \mathrm{~s}$ the scientists divided into two groups: "in favour" and "against" the use of nuclear energy. The project of the transition from nuclear energy to a new energy system using renewable energy sources (for example, solar hydrogen) is being worked out.

Analyzing international studies in the 1990s, it can be found that in this decade there was a shift in understanding what is a new source of energy: as such, nuclear power is gradually getting less 
understood, renewable energy sources are talked about more and more as new energy sources. Here we are talking about research specifically devoted to the attitude to renewable energy sources, and not on the economic or environmental assessment of their exploitation.

In the 2000s for the first time, public opinion polls began, including the opinion of the younger generation. In this connection, in the scientific community there was an urgent recommendation to introduce in the educational process, starting with the junior classes, educational disciplines, for example, nuclear physics. Scientists make the forecast that the future generation will be professionals and make adequate solutions in relation to the reality of the environmental and climate situation.

In the 2010s among international scientific publications one can find a lot of research on the relation to new energy sources conducted by the USA, Norway, Switzerland, Poland, Romania, Greece, Portugal, etc. Unlike the studies on the attitude to climate change covering almost the entire planet, this trend is spread mainly in Europe and in the United States - in those regions in which new sources of energy begin to play significant roles. But in some regions local population did not give a positive response to the use of new energy sources. The need to overcome hostility results in the research on the detection of effective communication channels that can improve the attitude of the population to new sources of energy. As in the case of research on climate change, scientists involved in the research on new sources of energy are interested in the attitude of young people to it - adolescents, students.

In the 1950s and 1960s, Russian scientists were interested in the nature of the origin of stars, galaxies, atomic energy, and chemical elements. In the 1970s and 1980s domestic researchers paid attention not to studying the relationship to new sources of energy, but to their use, understanding under the new source nuclear energy only.

In the 1990s, alternative (non-nuclear) energy sources are being searched for, which will help to save and restore an ecologically clean living environment. At the same time, the publications contain the idea of S.V. Vernadsky as a concept of the future transition to a different type of thinking in the anthroposphere.

In the 2000s as before, domestic studies devoted to new sources of energy do not contain any discussion of the attitude to these sources. But there is a shift in understanding what new energy sources are: instead of the atom, renewable energy is now considered to be a new source. Domestic research is focused on the increasing role of non-traditional and renewable energy sources, prospects for their use, etc.

In 2010, the spectrum of the possible use of renewable energy sources for the purposes of socio-economic development is worked out, recommendations are given on the preservation of non-renewable sources, the introduction of a conceptual strategy for the development of "green cities" and the formation of an information space on climate change and new energy sources.

\section{References}

Alemasov, V.Ye. (1980). Teoriya raketnykh dvigateley [The theory of rocket engines]. Moscow.

Ambartsumian, V.A. (1958). On the Evolution of Galaxies. In Bulletin of the Academy of Sciences [Separate print from the News of the Academy of Sciences of the Armenian SSR (series of physical and mathematical sciences)], XI (5).

Amerkhanov, R.A., Kasyanov, R.S., Milovanov, M.I. (2016). Using the potential of renewable energy in the Krasnodar Territory. In Innovations in agriculture, 5 (20), 25-28. 
Amerkhanov, R.A., Kirichenko, A.S., Kulichkina, A.A., Murtazaeva, Yu.L. (2015). Features of the use and development of renewable energy in the Krasnodar Territory. In Bulletin of Agrarian Science of the Don, 1 (29), 26-38.

Avadanei, C. (2009). Learning to Embrace Nuclear Physics through Education [7 $7^{\text {th }}$ International Conference of the Balkan-Physical-Union], Alexandroupolis, Greece, 2009.

Avakyan, S.V., Voronin, N.A. (2012). Energy of climate change. In Academy of Energy, 5 (49), 24-35.

Avduyevskiy, V.S. et al. (1986). Razvitiye idey K.E. Tsiolkovskogo ob industrializatsii kosmicheskogo prostranstva [Development of ideas of KE. Tsiolkovsky on the industrialization of outer space], In K.E. Tsiolkovskiy i problemy razvitiya nauki i tekhniki [K.E. Tsiolkovsky and the problems of the development of science and technology], 48.

Bagrova, L.A. (2009). Sovremennyye tendentsii razvitiya vozobnovlyayemoy energetiki v mire [Current trends in the development of renewable energy in the world], In Kul'tura narodov Prichernomor'ya [Culture of the peoples of the Black Sea region], 159, 39-46.

Bhabha, H.J. (1955). The Peaceful Uses of Atomic Energy, In Bulletin of the Atomic Scientists, 11(8), 280-284.

Bigerna, S., Polinori, P. (2015). Assessing the Determinants of Renewable Electricity Acceptance Integrating Meta-Analysis Regression and a Local Comprehensive Survey, In Sustainability (20711050), 7(9), 11909-11932.

Bockris, J. (1979). Energy: the solar-hydrogen alternative. New York, Halsted Press, 1975. $381 \mathrm{c}$.

Burgasov, P.N., Ioyrysh, A.I., Petros'yants, A.M. (1986). Sovetskoye atomnoye parvo [Soviet Atomic Law]. Moscow.

Canilo, P.M. (2016). Energy and global warming. In Problems of Mechanical Engineering, 19, 54-63.

Cebotari, S., Benedek, J. (2017). Renewable Energy Project as a Source of Innovation in Rural Communities: Lessons from the Periphery, In Sustainability (2071-1050), 9(4), 1-16.

Cockcroft, J. (1950). The Development and Future of Nuclear Energy, In Bulletin of the Atomic Scientists, 6(11), 325-331.

Culley, M.R., Carton, A.D., Weaver, S.R., Ogley-Oliver, E., Street, J.C. (2011). Sun, wind, rock and metal: attitudes toward renewable and non-renewable energy sources in the context of climate change and current energy debates, In Current Psychology, 30(3), 215-233.

Dahl, R.A., Brown Jr., R.S. (1952). Domestic Control of Atomic Energy, In Bulletin of the Atomic Scientists, 8(3), 88-91.

Danilov-Danilyan, V.I., Losev, K.S. (1998). Problems of sustainable development of mankind, In Russia in the surrounding world [International Independent Ecological and Political Science Journal], Moscow, 1-8.

Ecological housing construction. Energy saving problems (1997). Avrorin, A.V., Ogorodnikov, I.A., Chernova, G.V., Chinnov, E.A. [Analytical review], Novosibirsk, 71 p.

Engoyan, O.Z. (2011). Adaptation to climate change: energy aspects. In The Bulletin of the Altai Science, 1, 109-113.

Ershov, A.G., Shubnikov, V.L., Shultz, L.A. (2014). Thermal waste neutralization: theory and practice, myths and legends. In Solid household waste, 6 (96), 48-55. 
Essays on the Universe (1959). Vorontsov-Velyaminov, B.A. [Library series. Publishing House "Nauka"], Moscow, 672 p. Essays on Mineralogy and Geochemistry (1959); Fersman, A.E. [Nauka Publishers], Moscow, 192 p.

Frank-Kamenetsky, D.A. (1959). The origin of chemical elements. In Advances in Physical Sciences, 7.

Gerald, R. Theory of energy-balance climate models. In National Center for Atmospheric Research, 2033-2043.

Gipe, P. (1990). New attitudes toward wind, In Independent Energy, 20(3), 62-65.

Goldschmidt, B. (1962). The French Atomic Energy Program, In Bulletin of the Atomic Scientists, 18(7), 39-42.

González, A.M., Sandoval, H., Acosta, P., Henao, F. (2016). On the Acceptance and Sustainability of Renewable Energy Projects-A Systems Thinking Perspective, In Sustainability (2071-1050), 8(11), $1-21$.

Hart, P., Nisbet, E. (2012). Boomerang effects in communication: how motivated reasoning and identity cues amplify opinion polarization about climate mitigation policies. In Communication research, 39 (6), 701-723.

Kanilo, P.M., Kostenko, K.V. (2008). Perspektivy stanovleniya vodorodnoy energetiki i transporta [Prospects for the development of hydrogen energy and transport], In Avtomobil'nyy transport [Automobile transport], 23.

Kanilo, P.M., Shubenko, A.L. (2017). Heat power engineering. Fuel and environmental problems and development prospects. In Problems of Mechanical Engineering, 20 (1), 69-77.

Keramitsoglou, K.M. (2016). Exploring adolescents' knowledge, perceptions and attitudes towards Renewable Energy Sources: A colour choice approach, In Renewable and Sustainable Energy Reviews, 59, 1159-1169.

Kilinc, A., Stanisstreet, M., Boyes, E. (2009). Incentives and disincentives for using renewable energy: Turkish students' ideas. In Renewable and sustainable energy reviews, 13 (5), 1089-1095.

Klæboe, R., Sundfør, H.B. (2016). Windmill Noise Annoyance, Visual Aesthetics, and Attitudes towards Renewable Energy Sources, In International Journal of Environmental Research \& Public Health, 13(8), 1-19.

Koptyug, V.A. (1992). United Nations Conference on Environment and Development - preparatory process and outcomes [United Nations Conference on Environment and Development, Rio de Janeiro, June 1992], Novosibirsk [SB RAS], 5-23.

Kramish, A. (1959). Atomic Energy in the USSR, In Bulletin of the Atomic Scientists, 15(8), 322-328.

Krohn, S., Damborg, S. (1999). On public attitudes towards wind power, In Energy Efficiency, Policy and the Environment, Renewable Energy, 16(1), 954-960

Kuper, A. (1954) A Look at the New Atomic Energy Law, In Bulletin of the Atomic Scientists, 10(10), 389-392.

Löfstedt, R.E. (1991). Public perceptions towards various energy sources in Sweden, In Energy, 16(7), 1059-1065.

Loiter, J.M, Norberg-Bohm, V. (1999). Technology policy and renewable energy: public roles in the development of new energy technologies, In Energy Policy, 27(2), 85-97 
Lukutin, B.V. (2008). Vozobnovlyayemyye istochniki elektroenergii [Renewable sources of electric power]. Tomsk.

Lyman, E.S. (1996). Weapons Plutonium: Just can it, In Bulletin of the Atomic Scientists, 52(6), 48-52.

Magomedova, N.A., Balayantc, V.A. (2003). Ekonomicheskiye issledovaniya v oblasti ispol'zovaniya netraditsionnykh vozobnovlyayemykh istochnikov energii [Economic research in the use of non-traditional renewable energy sources], In Voprosy strukturizatsii ekonomiki [Issues of structuring the economy], 1, 68-73.

Maharik, M., Fischhoff, B. (1993). Contrasting perceptions of the risks of using nuclear energy sources in space, In Journal of Environmental Psychology, 13(3), 243-250.

Markov, N. (2008). «Terminatory» uglevodorodnoy epokhi [Terminators of the Hydrocarbon Age], In Neft' Rossii [Oil of Russia], 3, 88-90.

Medvedev, L.N., Kozenko, K.Yu., Komarova, O.P. (2015). Prospects for medium-sized cities in the development of green economies. In Izvestiya of the Nizhnevolzhsky agro-university complex: Science and higher vocational education, 4 (40), 214-221.

Mesyatc, G.A., Prokhorov, M.D. (2004). Vodorodnaya energetika i toplivnye elementy [Hydrogen energy and fuel elements], In Vestnik Rossiiskoi Akademii Nauk [Bulletin of the Russian Academy of Sciences], 74(7), 579-590.

Michel, A.H., Buchecker, M., Backhaus, N. (2015). Renewable energy, authenticity, and tourism: social acceptance of photovoltaic installations in a Swiss Alpine region, In Mountain Research and Development, 35(2), 161-170.

Misharin, V.N. (1986). Mirnoye ispol'zovaniye atomnoy energii: pravovyye voprosy [Peaceful use of atomic energy: legal issues]. Moscow.

Mizhinskiy, M.Yu., Sigutina, M.A. (2008). Soyedinennyye Shtaty Ameriki v gonke za investitsii v al'ternativnuyu energetiku [United States of America in the race for investment in alternative energy], In Innovatsii [Innovations], 4, 84-86.

Mroczek, B., Kurpas, D. (2014). Social Attitudes towards Wind Farms and other Renewable Energy Sources in Poland, In Medycyna Środowiskowa, 17(4), 19-28.

Othman, M.Y., Sopian, K. (1999). Renewable energy education for Asean, In Energy Efficiency, Policy and the Environment, Renewable Energy, 16(1), 1225-1230.

Perminov, E.M. (2007). Development of decentralized renewable energy and solving environmental problems in Russia. In ELECTRO, 3, 2-9.

Petrakopoulou, F. (2017). The Social Perspective on the Renewable Energy Autonomy of Geographically Isolated Communities: Evidence from a Mediterranean Island, In Sustainability (20711050), 9(3), 1-8.

Pidgeon, N., Demski, C.C. (2012). From nuclear to renewable: Energy system transformation and public attitudes, In Bulletin of the Atomic Scientists, 68(4), 41-51.

Prokofiev, A.V. (2011). Climate justice: the Russian context. In Ethical thought, 11, 140-163.

Protsenko, A. N. (1985). Energiya budushchego [The energy of the future]. Moscow.

Post, R. (1957). Application of the physics of high-temperature plasma to the implementation of controlled reactions of fusion of atomic nuclei. Physics of the atomic nucleus and particles in UFN, 61 (4), [Online]. 
Ravino, A.V. (2016). Economics of Climate Change [Proceedings of BSTU, 7], In Economics and Management, 7 (189), 158-162.

Rees, M. (1971). New interpretation of extragalactic radio sources. Nature, 229, 312 - 317/

Ribeiro, F., Ferreira, P., Araújo, M., Braga, A.C. (2014). Public opinion on renewable energy technologies in Portugal, In Energy, 69, 39-50.

Ruebhausen, O.M., von Mehren, R.B. (1953). The Atomic Energy Act and the Private Production of Atomic Power, In Harvard Law Review, 66(8), 132-178.

Saha, P., Idsø, J. (2016). New hydropower development in Norway: Municipalities' attitude, involvement and perceived barriers, In Renewable and Sustainable Energy Reviews, 61, 235-244.

Schonborn, S., Gellrich, A., David, M. (2014). Local churches in the diffusion process of renewable energies-a key to new milieus? In GAIA - Ecological Perspectives for Science and Society, 23(3), 236-242.

Schurr, S.H. (1965). The Economics of Atomic Power, In Bulletin of the Atomic Scientists, 21(1), $22-25$.

Shardyko, S.K. (1998). Philosophy of Nuclear Power. In Social Sciences and the Present, 2 , 152-161.

Sokol'skiy, A.K. (2007). Netraditsionnyye $i$ vozobnovlyayemyye istochniki energii [Nontraditional and renewable sources of energy]. Moscow, $104 \mathrm{p}$.

Steel, B.S., Pierce, J.C., Warner, R.L., Lovrich, N.P. (2015). Environmental Value Considerations in Public Attitudes About Alternative Energy Development in Oregon and Washington, In Environmental Management, 55(3), 634-645.

The Origin of Cosmic Rays (1963). Ginzburg V.L., Syrovatskii, S.I. [Publishing house of the USSR Academy of Sciences], Moscow, 384 p.

Tyukhov, I.I. (2009). Vozobnovlyayemaya energetika i lesnoye khozyaystvo dlya ustoychivogo budushchego [Renewable energy and forestry for a sustainable future], In Vestnik Povolzhskogo gosudarstvennogo tekhnologicheskogo universiteta. Seriya: Les. Ekologiya. Prirodopol'zovaniye [Bulletin of the Volga State Technological University. Series: Forest. Ecology. Nature management], 2.

Unsold, A., (1958). Sources of stellar energy and the evolution of stars. In Physics of our days, 7, [Online]

White, L. (2004). Nauka o kul'ture: izbrannoe [Science of culture: selectas]. Moscow, $1062 \mathrm{p}$.

Yablokov, A.V. (1995). The Nuclear Mythology of the End of the 20th Century. In The New World, 2 [Online].

Yanshin, A.D. (1999). Scientific problems of nature protection and ecology. In Ecology and Life, 3, [Online]. 


\title{
Историографический обзор \\ научных исследований по проблеме \\ отношения населения к новым источникам энергии
}

\author{
К.В. Резникова, Ю.С. Замараева \\ Сибирский федеральный университет \\ Россия, 660041, Красноярск, пр. Свободный, 79
}

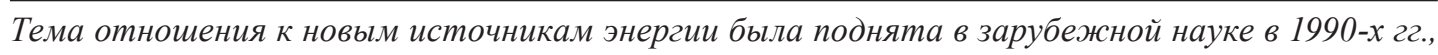
отечественные ученые до сих пор не уделяют этому направлению должного внимания. $B$ сфере изучения отношения к новым источникам энергии за рубежом поворотным десятилетием также стали 1990-е гг., на которые пришелся переход в понимании того, что является новым источником энергии: в качестве такового постепенно перестает пониматься ядерная энергия; в качестве новых речь все больше ведется о возобновляемых источниках энергии. Данное направление в науке с его возникновения и по настоящее время распространено в основном в Европе и в США - в тех регионах, в экономике которых новые источники энергии начинают играть значительные роли.

Ключевые слова: глобальное изменение климата, новые источники энергии, возобновляемые источники энергии, отношение населения, историография изучения новых источников энергии.

Исследование выполнено при финансовой поддержке Российского фонда фундаментальных исследований, Правительства Красноярского края, Красноярского краевого фонда поддержки научной и научно-технической деятельности в рамках научного проекта № 17-16-24601.

Научная специальность: 24.00.00 - культурология. 